\title{
PIET MEIRING
}

D Tutu

(Emeritus Archbishop, Anglican Church)

I do not know precisely when I first met Piet Meiring. I think it was when I was still General Secretary of SACC in the late 70s or early 80s when the white Dutch Reformed Church was hostile to the Council and friendly towards the Apartheid Government. When ever it was, I have never forgotten him. He had a gentle demeanor with a soft smile always playing round the corners of his mouth. Somehow he managed to combine a biblical concern for righteousness and compassion for the casualties of injustice and oppression with an ability to fraternize with those who did support apartheid. It was an unusual talent. He had credibility for both these antithetical groups. He was the quintessential so called marginal person who sought to join two opposing groups. And so he could be elected moderator of the Eastern Transvaal Synod of the Dutch Reformed Church and be welcomed warmly when I nominated him for membership of a committee of the TRC. We were determined to make the TRC as representative of our nation as possible especially in the face of the hostility of the Afrikaner establishment who claimed long before the TRC had ever begun to work that it would be biased in favor of the ANC and be but a ploy to continue an alleged ANC witch hunt against Afrikaners. Piet was just the right person. His integrity was impeccable and thus whatever assessment he would make of the TRC would find acceptance even if reluctant among his fellow Afrikaners. He turned out to be a wonderful and valuable acquisition. He became a member of the Reparations and Rehabilitation Committee, one of three Committees of the TRC. It is a testimony to Piet's affable nature and his capacity to disarm people that his constant companion during his term of office turned out to be Thom Manthata, a radical Black Consciousness adherent who had worked for the SACC had been tortured whilst in detention without trial and had been convicted in the Delmas Treason Trial (the conviction had been set aside on appeal because of irregularities and Thom and his fellow trialists were released from Robben Island after a short sojourn). Thom is a gentle person but politically radical and not to be trifled with - yet Piet struck up a close relationship with Thom that has continued to this day. They must have presented a strange picture, the ultimate odd couple, the University Professor dominee and the black activist when they visited those who were 
designated victims to discuss likely measures for reparation. Odd but compatible.

And Piet has been so keen and done all he could to find opportunities to show that the former Chair of the TRC despite all evidence to the contrary was really not an ogre.

Yes we give thanks for this son of the soil - an outstanding agent of reconciliation. And Inza his beautiful spouse has been a superb helpmeet. 